\title{
Description of the larval instars of Gonatopus bartletti Olmi, 1984 (Hymenoptera: Dryinidae)
}

\author{
A. GUGLIELMINO ${ }^{1}$, C. BÜCKLE ${ }^{2} \&$ G. MOYA-RAYGOZA ${ }^{3}$ \\ ${ }^{\prime}$ Department of Plant Protection, University of Tuscia, Via S. Camillo de Lellis, 01100 Viterbo, Italy. \\ E-mail: guglielm@unitus.it \\ ${ }^{2}$ Neckarhalde 48, Tübingen, Germany \\ ${ }^{3}$ Departamento de Botanica y Zoologia, Centro Universitario de Ciencias Biologicas y Agropecurias \\ (CUCBA), Universidad de Guadalajara, Km 15.5 carretera Guadalajara- Nogales, Las Agujas, Zapopan, \\ Codigo Postal 45110, Apartado Postal 139, Jalisco, Mexico
}

\begin{abstract}
The postembryonic development and external morphology of each larval instar of Gonatopus bartletti Olmi, 1984 are described and illustrated. The affinities among the immature and mature larvae of $G$. bartletti and corresponding instars of other species of the same subfamily are discussed. The mature larva shows a peculiar structure never observed in other Gonatopodinae species; near the base of each mandible is a peculiar subrectangular heavily sclerotized and dark pigmented area with a lens-shaped transparent protuberance in its anterolateral angle. Its function is unknown.
\end{abstract}

Key words: Auchenorrhyncha, Fulgoromorpha, Cicadomorpha, Gonatopodinae, postembryonic development, morphology

\section{Introduction}

Dryinidae is a highly specialized family of Aculeata that is widely distributed throughout the world and includes at least 1400 species (Olmi, 1999). In their postembryonic development, Dryinidae have two types of larvae, mature and immature, which differ in shape, physiology, and feeding habits. The immature larvae are sacciform according to the terminology used by Clausen (1940), and live as parasitoids of juvenile instars or adults of Auchenorrhyncha. The mature larva is hymenopteriform (Clausen 1940); this stage kills the host by feeding on its internal tissues, and, then, moves about freely for a short time until it spins a cocoon for pupation. 